\title{
PENGARUH PENERAPAN SISTEM AGRIBISNIS TERHADAP PENDAPATAN USAHATANI MENTIMUN (Cucumis sativus L.) DI KECAMATAN RANTAU KABUPATEN ACEH TAMIANG
}

\author{
${ }^{1}$ Supristiwendi, SP, M.Si/ ${ }^{2}$ Monika Azizah \\ 1Dosen Tetap Program Studi Agribisnis Fakultas Pertanian \\ 2Mahasiswa Fakultas Pertanian Program Studi Agribisnis \\ Universitas Samudra, Langsa-Aceh
}

\begin{abstract}
Abstrak
Lokasi penelitian dilakukan di Kecamatan Rantau Kabupaten Aceh Tamiang dengan pertimbangan bahwa daerah tersebut merupakan salah satu kecamatan yang berada di Kabupaten Aceh Tamiang yang mengusahakan budidaya mentimun. Penelitian ini dilakukan dengan metode survey. Objek dalam penelitian ini adalah para petani yang berusahatani mentimun (Cucumis sativus L.) yang berada di Kecamatan Rantau Kabupaten Aceh Tamiang. Ruang lingkup dalam penelitian ini adalah pendapatan usahatani, subsistem sarana produksi, subsistem produksi usahatani dan subsistem penanganan pasca panen.

Adapun tujuan dari penelitian ini adalah untuk mengetahui pengaruh penerapan subsistem sarana produksi, subsistem produksi usahatani dan subsistem penanganan pasca panen terhadap pendapatan usahatani mentimun di Kecamatan Rantau Kabupaten Aceh Tamiang.

Rata-rata umur petani mentimun adalah 41,2 tahun, dengan masa pendidikan 8,9 tahun, pengalaman berusahatani 13,3 tahun dan besarnya tanggungan keluarga rata-rata 4 orang. Rata-rata umur petani tergolong produktif, masa pendidikan tergolong rendah karena masa pendidikan 8,9 tahun antara SLTP dan SLTA, sedangkan jumlah tanggungan keluarga 4 orang relatif tinggi.

Hasil Penelitian dimana rata-rata luas lahan garapan usahatani mentimun di Desa Jamur Jelatang adalah 0,23 Ha, Desa Jamur Labu 0,16 Ha dan Desa Ingin Jaya 0,16 Ha. Sedangkan rata-rata luas garapan petani mentimun di daerah penelitian adalah 0,18 $\mathrm{Ha}$. Rata-rata biaya produksi usahatani mentimun di daerah penelitian yaitu Rp. 2.046.947,-- per usahatani dan Rp. 11.371.926,- per hektar. Penggunaan biaya produksi terbesar terdapat di Desa Jamur Jelatang yaitu Rp. 2.495.991 per usahatani. Rata-rata pendapatan kotor/nilai produksi usahatani mentimun didaerah penelitian adalah sebesar Rp. 4.583.333,-/UT atau Rp. 25.462.963,-/Ha, sedangkan rata-rata pendapatan bersih usahatani mentimun adalah Rp. 2.536.387,-/UT atau Rp. 14.091.037,-/Ha.

Dari analisis statistik dengan menggunakan Regresi Linier Berganda diperoleh persamaan regresi yaitu $Y=-18,89+0,062 X_{1}+0,21 X_{2}+1,41 X_{3}$. Hasil perhitungan diperoleh $\left(R^{2}\right)=0,70$ atau $70 \%$. Ini berarti subsistem sarana produksi, subsistem produksi usahatani dan subsistem penanganan pasca panen mempengaruhi pendapatan usahatani mentimun di daerah penelitian sebesar $70 \%$ sedangkan $30 \%$ di pengaruhi faktor-faktor lain diluar penelitian yang tidak dihitung nilainya, seperti faktor harga, permintaan, penawaran dan sebagainya. Hasil pengujian secara serempak menunjukkan bahwa subsistem sarana produksi, subsistem produksi usahatani dan subsistem penanganan pasca panen secara serempak berpengaruh sangat nyata terhadap pendapatan usahatani mentimun di Kecamatan Rantau Kabupaten Aceh Tamiang. Hasil pengujian secara parsial menunjukkan bahwa subsistem sarana produksi, subsistem produksi usahatani dan subsistem penanganan pasca panen secara parsial berpengaruh sangat nyata terhadap pendapatan usahatani mentimun di Kecamatan Rantau Kabupaten Aceh Tamiang.
\end{abstract}

Kata Kunci: Subsistem Agribisnis, Usahatani, Pendapatan

\section{Pendahuluan}

Komoditas hortikultura yang terdiri dari tanaman buah-buahan, sayuran, tanaman hias dan tanaman obat merupakan komoditas yang sangat prospektif untuk dikembangkan melalui usaha agribisnis, mengingat potensi serapan pasar didalam negeri dan pasar internasional terus meningkat. Sayuran adalah salah satu komponen dari menu makanan yang sehat, maka tidak heran bila kebutuhan sayuran dewasa ini semakin meningkat sejalan dengan kesadaran masyarakat tentang kesehatan. Diantara bermacam-macam jenis sayuran yang dapat dibudidayakan, tanaman mentimun merupakan salah satu komoditas sayuran buah yang memiliki nilai komersial dan prospek yang tinggi.

Meskipun bukan merupakan tanaman asli Indonesia, tetapi mentimun sudah sangat dikenal oleh masyarakat Indonesia. Jenis sayuran ini dengan sangat mudah ditemukan AGRISAMUDRA, Jurnal Penelitian Vol.2 No. 2 Januari-Juni 2015 hampir diseluruh pelosok Indonesia. Mentimun (Cucumis sativus L.) adalah salah satu sayuran buah yang banyak dikonsumsi segar oleh masyarakat. Nilai gizi mentimun cukup baik karena sayuran buah ini merupakan sumber mineral dan vitamin.

Tanaman mentimun termasuk kedalam keluarga labu-labuan (Cucurbitaceae), yang sedikitnya memiliki 750 tanaman yang tumbuh di dunia. Kedudukan tanaman mentimun dalam taksonomi tumbuhan adalah sebagai berikut :

Devisio : Sphermatophyta

Sub Divisio : Angiospermae

Kelas : Dicotyledonae

Ordo : Curcubitales

Family : Curcubitaceae

Genus : Cucumis

Spesies : Cucumis sativus L.

Aceh Tamiang merupakan daerah yang memiliki luas lahan produktif dan memiliki 
luas produksi sayuran sebanyak 2.310,80 dari 12 kecamatan. Untuk mengetahui gambaran mengenai keadaan jumlah produksi dari usahatani sayur mayur setiap Kecamatan di
Kabupaten Aceh Tamiang dapat dilihat pada tabel I-2 berikut:

Tabel I-2: Jenis-jenis Komoditi Sayur Mayur di Kabupaten Aceh Tamiang, 2014

\begin{tabular}{|c|l|c|c|c|c|}
\hline No & \multicolumn{1}{|c|}{ Jenis Komoditi } & $\begin{array}{c}\text { Luas tanam } \\
(\mathrm{Ha})\end{array}$ & Luas panen $(\mathrm{Ha})$ & Produksi (Ton) & $\begin{array}{c}\text { Produktivitas } \\
(\text { Ton/Ha) }\end{array}$ \\
\hline 1. & Cabai Besar & 136 & 124 & 201,10 & 3,17 \\
2. & Kacang Panjang & 167 & 152 & 505,40 & 3,30 \\
3. & Sawi & 14 & 15 & 1,90 & 0,10 \\
4. & Mentimun & 120 & 108 & 588,70 & 5,50 \\
5. & Terung & - & 90 & 384,90 & 4,30 \\
6. & Tomat & 262 & 245 & - & - \\
7. & Kangkung & 216 & 200 & 224,20 & 0,90 \\
8. & Bayam & 999 & 934 & 2310,50 & 1,10 \\
\hline & Jumlah & 940,37 \\
\hline
\end{tabular}

Sumber : Dinas Pertanian dan Peternakan Kabupaten Aceh Tamiang, 2015

Dari tabel I-2 dapat dilihat bahwa luas lahan, produksi, dan produktivitas usahatani berbeda antara satu komoditi dengan komoditi yang lain yang berada di Kabupaten Aceh Tamiang, dapat dilihat jumlah total produksi tanaman sayuran secara keseluruhannya sebesar 2310,80 ton dan jumlah produktivitasnya sebesar 18,37 ton/ha.

Kecamatan Rantau merupakan salah satu Kecamatan di Kabupaten Aceh Tamiang yang mengusahakan usahatani mentimun. Kecamatan Rantau terdiri dari 16 desa, dimana terdapat 12 desa yang melakukan usahatani sayuran mentimun.

Usahatani mentimun merupakan salah satu usaha yang dilakukan oleh petani yang berada di Kecamatan Rantau untuk mendapatkan keuntungan dan kesejahteraan dari pertanian. Usahatani merupakan tempat dimana seseorang atau sekumpulan orang berusaha mengelola atau memanfaatkan sumber daya alam yang berada disekitarnya, dengan menggunakan tenaga kerja, modal dan keterampilan dengan tujuan berproduksi untuk menghasilkan sesuatu di lapangan pertanian.

Agribisnis adalah suatu usahatani yang berorientasi komersial atau usaha bisnis pertanian dengan orientasi keuntungan. Salah satu upaya yang dapat ditempuh agar dapat meningkatkan pendapatan usahatani adalah dengan penerapan konsep pengembangan sistem agribisnis terpadu, yaitu apabila sistem agribisnis yang terdiri dari subsistem sarana produksi, subsistem budidaya, subsistem pengolahan dan pemasaran dikembangkan secara terpadu dan selaras. Penerapan agribisnis merupakan kesatuan atau kumpulan dari unsur-unsur agribisnis yang saling berhubungan untuk dapat mencapai tujuan dan sasaran bersama, menggunakan dan mengeluarkan produk agribisnis melalui pengendalian dalam suatu proses yang telah direncanakan. Oleh karena itu penerapan agribisnis perlu dilakukan untuk memajukan usahatani agar mendapatkan hasil yang maksimal dalam setiap produksi pertanian.

Subsistem sarana produksi meliputi alat-alat produksi yang digunakan untuk keperluan usahatani, seperti modal, tanah, air, tenaga kerja, penyediaan bibit, pupuk, pestisida, cangkul, traktor, sprayer, plastik mulsa, lanjaran dan lain-lain sebagainya. Oleh karena itu subsistem sarana produksi menjadi salah satu faktor penting didalam kegiatan dibidang pertanian.

Subsistem produksi usahatani adalah cara petani dalam mengelola sumber daya alam yang ada untuk menghasilkan suatu produk pertanian yang baik dan bermutu tinggi dengan menggunakan faktor-faktor produksi seperti, tanah, air, tenaga kerja, modal, pupuk, benih, pestisida serta penggunaan teknologi pertanian secara tepat.

Subsistem penanganan pasca panen merupakan tindakan atau kegiatan yang dilakukan setelah pemanenan atau sering disebut dengan pasca panen agar hasil dari pertanian siap dan aman untuk digunakan oleh konsumen dan atau agar dapat diolah lebih lanjut oleh lembaga industri. Dalam penelitian ini subsistem penanganan pasca panen pada sayuran dilakukan untuk tujuan penyimpanan, transportasi, dan pemasaran.

Berdasarkan uraian yang telah diuraikan sebelumnya maka penulis tertarik untuk meneliti tentang pengaruh penerapan sistem agribisnis terhadap pendapatan usahatani mentimun di Kecamatan Rantau Kabupaten Aceh Tamiang.

\section{Identifikasi Masalah}

"Apakah subsistem sarana produksi, subsistem produksi usahatani dan subsistem penanganan pasca panen berpengaruh terhadap pendapatan usahatani mentimun di Kecamatan Rantau Kabupaten Aceh Tamiang?". 


\section{Tujuan Penelitian}

“Untuk mengetahui pengaruh penerapan subsistem sarana produksi, subsistem produksi usahatani dan subsistem penanganan pasca panen terhadap pendapatan usahatani mentimun di Kecamatan Rantau Kabupaten Aceh Tamiang".

\section{Hipotesis}

"Penerapan subsistem sarana produksi, subsistem produksi usahatani dan subsistem penanganan pasca panen berpengaruh terhadap pendapatan usahatani mentimun di Kecamatan Rantau Kabupaten Aceh Tamiang".

\section{METODE PENELITIAN}

Lokasi penelitian dilakukan di Kecamatan Rantau Kabupaten Aceh Tamiang dengan pertimbangan bahwa daerah tersebut merupakan salah satu kecamatan yang berada di Kabupaten Aceh Tamiang yang mengusahakan budidaya mentimun. Penelitian ini dilakukan dengan metode survey. Menurut Nazir (2005:56), metode survey adalah penyelidikan untuk memperoleh fakta dari gejala-gejala dan mencari keteranganketerangan secara faktual baik tentang institusi sosial, ekonomi atau politik dari suatu kelompok ataupun suatu daerah. Penentuan lokasi penelitian dilakukan secara sengaja (Purposive). Menurut Sugiyono (2010:122) "Purposive Sampling adalah teknik penentuan sampel dengan pertimbangan tertentu".

Objek dalam penelitian ini adalah para petani yang berusahatani mentimun Tabel II-1: Jumlah Populasi dan Jumlah Sampel Desa yang Memiliki Usahatani Mentimun di Kecamatan Rantau Kabupaten Aceh Tamiang, 2014

\begin{tabular}{|c|l|c|c|}
\hline No & \multicolumn{1}{|c|}{ Nama Desa } & Populasi & Sampel \\
\hline 1 & Jamur Jelatang & 37 & 11 \\
2 & Jamur Labu & 32 & 10 \\
3 & Ingin Jaya & 30 & 9 \\
\hline \multicolumn{1}{|c|}{ Jumlah } & 99 & 30 \\
\hline
\end{tabular}

Sumber : BPP Kecamatan Rantau dalam Angka, (2015)

Tabel II-1 menunjukan bahwa jumlah populasi petani mentimun yaitu sebanyak 99 orang, dan diambil sampel sebanyak 30 orang yang terdiri dari Desa Jamur Jelatang sebanyak 11 orang, Desa Jamur Labu sebanyak 10 orang dan Desa Ingin Jaya sebanyak 9 orang.

\section{Pengumpulan Data}

Data yang digunakan dalam penelitian ini adalah data primer dan data sekunder. Data primer diperoleh melalui pengamatan langsung pada daerah yang menjadi objek penelitian yaitu petani mentimun yang berada di Kecamatan Rantau dan teknik observasi dan wawancara melalui daftar pertanyaan yang telah dipersiapkan.

Teknik pengumpulan data primer yang dilakukan yaitu:

- Observasi

Observasi yaitu dengan pengamatan langsung terhadap objek yang akan diteliti
(Cucumis sativus L.) yang berada di Kecamatan Rantau Kabupaten Aceh Tamiang. Ruang lingkup dalam penelitian ini adalah pendapatan usahatani, subsistem sarana produksi, subsistem produksi usahatani dan subsistem penanganan pasca panen. Waktu penelitian dilaksanakan pada Mei - Juni 2015.

\section{Teknik Penentuan Sampe}

Menurut Nana (2005:5), “sampel merupakan sebagian dari populasi yang paling tidak mempunyai ciri yang sama dengan populasinya untuk mewakili populasi yang ada". Kecamatan Rantau terdiri dari 16 desa, dari 16 desa tersebut terdapat 12 desa yang berusahatani mentimun. Dari 12 desa yang berusahatani mentimun diambil 3 desa secara purposive (sengaja) untuk dijadikan sampel dalam penelitian. Desa-desa tersebut yaitu Desa Jamur Jelatang, Desa Jamur Labu, dan Desa Ingin Jaya dipertimbangkan bahwa ketiga desa tersebut memiliki usahatani mentimun yang paling luas.

Metode pengambilan petani sampel dilakukan dengan menggunakan metode Simple Random Sampling. Menurut Sugiyono (2010:118) “dikatakan Simple (sederhana) karena pengambilan anggota sampel dari populasi dilakukan secara acak tanpa memperhatikan strata yang ada dalam populasi itu". 
Bahan kepustakaan yaitu dengan mengumpulkan data berupa teori-teori yang diperoleh dari literatur-literatur yang berhubungan dengan permasalahan yang ada dalam penelitian.

\section{Metode Analisis dan Pengujian Hipotesis}

Model analisis yang menunjukkan bentuk hubungan antara variabel-variabel bebas dengan variabel terikat dapat dirumuskan dalam bentuk Regresi Linear Berganda.

Persamaannya dapat ditulis sebagai berikut:

Dimana:

$$
Y=a_{0}+a_{1} X_{1}+a_{2} X_{2}+a_{3} X_{3}+e
$$

$\mathrm{Y} \quad=$ Pendapatan usahatani

(Rp/Ha/MT)

$\mathrm{X}_{1}=$ Subsistem Sarana Produksi (Skor)

$\mathrm{X}_{2}=$ Subsistem Produksi Usahatani

(Skor)

$\mathrm{X}_{3}=$ Subsistem Penanganan Pasca

Panen (Skor)

$a_{0}, a_{1}, a_{2}, a_{3}=$ Parameter yang dicari (koefisien masingmasing variabel bebas).

e $=$ Kesalahan pengganggu (error).

Koefisien Determinan bertujuan untuk mengetahui seberapa besar kemampuan variabel dependen menjelaskan variabel independen. Digunakan koefisien determinasi $\left(\mathrm{R}^{2}\right)$, dengan rumus:

$$
R^{2}=\frac{J \text { Kreg }}{\sum y^{2}}
$$

Dimana :

Tabel IV-1 : Rata-rata Karakteristik Petani Mentimun di Kecamatan Rantau, 2015.

\begin{tabular}{|c|l|c|c|c|c|}
\hline No & \multicolumn{1}{|c|}{ Desa Sampel } & $\begin{array}{c}\text { Umur } \\
\text { (Tahun) }\end{array}$ & $\begin{array}{c}\text { Pendidikan } \\
\text { (Tahun) }\end{array}$ & $\begin{array}{c}\text { Pengalaman } \\
\text { (Tahun) }\end{array}$ & $\begin{array}{c}\text { Jumlah Tanggungan } \\
\text { (Orang) }\end{array}$ \\
\hline 1. & Jamur Jelatang & 42,8 & 9,0 & 13,8 & 3,6 \\
2. & Jamur Labu & 41,0 & 8,7 & 13,6 & 3,3 \\
3. & Ingin Jaya & 39,7 & 9,0 & 12,6 & 3,8 \\
& & & & 40,0 & 10,7 \\
\hline \multicolumn{2}{|r|}{ Jumlah } & 123,5 & 26,7 & 13,3 & 4 \\
\hline
\end{tabular}

Sumber : Data Primer (diolah), 2015

Berdasarkan tabel IV-1 di atas, dapat dilihat bahwa rata-rata petani di daerah penelitian berumur 41,2 tahun ini berarti petani didaerah penelitian masih dalam usia produktif, usia produktif tergolong pada umur 15 sampai 60 tahun, tingkat pendidikan rata-rata 8,9 tahun, masa pendidikan masih tergolong rendah karena masa pendidikan 8,9 tahun antara SLTP dan SLTA. Hal ini menunjukkan bahwa sebagian besar petani telah lulus sekolah dasar dan sekolah lanjut tingkat pertama, sehingga dapat dikatakan bahwa pengetahuan petani sampel relatif masih rendah yang pada akhirnya dapat

\section{Luas Lahan Garapan}

$\begin{array}{cc}\mathrm{R}^{2}= & \begin{array}{c}\text { Koefisien Determinasi } \\ \text { (persentase hubungan } \mathrm{X}_{1},\end{array} \\ & \mathrm{X}_{2} \text { dan } \mathrm{X}_{3} \text { terhadap } \mathrm{Y} \text { ) } \\ \mathrm{JK} \text { reg }= & \text { Jumlah Kuadrat Regresi } \\ \Sigma \mathrm{y}^{2}= & \text { Jumlah Kuadrat Total } \\ \text { Untuk menguji secara serempak }\end{array}$ pengaruh variabel bebas $\left(X_{1}, X_{2}\right.$, dan $\left.X_{3}\right)$ terhadap variabel terikat $(Y)$, digunakan uji $F$ (Sudjana, 2005:355) menjelaskan "uji $F$ adalah metode pengujian yang dilakukan untuk mengetahui pengaruh variabel bebas secara bersama-sama terhadap variabel terikat". Digunakan rumus sebagai berikut :

Dimana:

$$
F=\frac{J K_{r e g} / k}{J K_{r e s} /(n-k-1)}
$$

untuk regresi

$$
\begin{array}{ll}
\mathrm{K} & =\text { Banyaknya variabel bebas } \\
\mathrm{JK}_{\text {res }} & =\text { Jumlah kuadrat-kuadrat }
\end{array}
$$

residu

Dengan ketentuan :

$\mathrm{F}_{\text {cari }}>\mathrm{F}_{\text {tabel, }}$ pada taraf $0,05=95 \%$ dan $0,01=$ 99\%, maka terima Ha tolak $\mathrm{H}_{0}$

$\mathrm{F}_{\text {cari }} \leq \mathrm{F}_{\text {tabel, }}$, pada taraf $0,05=95 \%$ dan $0,01=$ 99\%, maka tolak Ha terima $\mathrm{H}_{0}$

\section{HASIL DAN PEMBAHASAN}

\section{Karakteristik Petani \\ Untuk lebih jelasnya mengenai keadaan karakteristik petani di daerah penelitian dapat dilihat pada tabel IV-1 berikut :}


dari masing-masing desa sampel di daerah penelitian dapat dilihat pada tabel IV-2 berikut ini :

Tabel IV-2 : Rata-rata Luas Lahan Garapan Usahatani Mentimun di Kecamatan Rantau, 2015.

\begin{tabular}{|c|l|c|}
\hline No & \multicolumn{1}{|c|}{ Desa Sampel } & \multicolumn{1}{|c|}{$\begin{array}{c}\text { Luas Lahan Garapan } \\
\text { (Ha) }\end{array}$} \\
\hline 1. & Jamur Jelatang & 0,23 \\
2. & Jamur Labu & 0,16 \\
3. & Ingin Jaya $\quad$ Jumlah & 0,16 \\
\hline \multicolumn{2}{|c|}{ Rata-rata } & 0,54 \\
\hline \multicolumn{2}{|c|}{0,18} \\
\hline
\end{tabular}

Sumber : Data Primer (diolah), 2015

Dari tabel IV-2 di atas dapat dilihat bahwa rata-rata luas lahan garapan petani mentimun di Kecamatan Rantau yaitu seluas 0,18 hektar, rata-rata luas lahan garapan Desa Jamur Jelatang yaitu seluas 0,23 hektar, ratarata Iuas Iahan Desa Jamur Labu dan Desa Ingin Jaya yaitu seluas 0,16 hektar. Luas lahan yang tersedia untuk tanaman mentimun mempengaruhi dalam penerapan sistem agribisnis usahatani mentimun. Hal ini menunjukkan bahwa potensi wilayah dalam pengembangan usahatani mentimun di
Kecamatan Rantau belum memadai, para petani memiliki luas lahan yang sempit untuk membudidayakan usahatani mentimun tersebut.

\section{Subsistem Sarana Produksi Usahatani Mentimun \\ Untuk lebih jelasnya mengenai rata-rata skor subsistem sarana produksi terhadap pendapatan usahatani mentimun di daerah penelitian dapat dilihat pada tabel IV-3 berikut ini:}

Tabel IV-3 : Rata-rata Skor Subsistem Sarana Produksi Terhadap Pendapatan Usahatani Mentimun di Kecamatan Rantau, 2015.

\begin{tabular}{|c|c|c|c|c|c|c|}
\hline \multirow[b]{2}{*}{ No } & \multirow{2}{*}{$\begin{array}{l}\text { Subsistem Sarana Produksi } \\
\text { Usahatani Mentimun }\end{array}$} & \multicolumn{3}{|c|}{ Desa Sampel } & \multirow[b]{2}{*}{ Jumlah } & \multirow[b]{2}{*}{ Rata-rata } \\
\hline & & $\begin{array}{l}\text { Jamur } \\
\text { Jelatang }\end{array}$ & $\begin{array}{l}\text { Jamur } \\
\text { Labu }\end{array}$ & Ingin Jaya & & \\
\hline \multirow{5}{*}{$\begin{array}{l}1 . \\
2 . \\
3 . \\
4 . \\
5 .\end{array}$} & Cara Perolehan Bibit & 2,7 & 2,5 & 2,4 & 7,7 & 2,6 \\
\hline & Pupuk yang digunakan & 2,4 & 2,5 & 2,3 & 7,2 & 2,4 \\
\hline & Jenis Pestisida & 2,4 & 2,4 & 2,2 & 7,0 & 2,3 \\
\hline & Alat Pengolahan Lahan & 2,6 & 2,6 & 2,6 & 7,8 & 2,6 \\
\hline & status Pengunaan Lanan & 2,5 & 2,6 & 2,6 & 7,7 & 2,6 \\
\hline
\end{tabular}

Sumber : Data Primer (diolah), 2015

Dari tabel IV-3 di atas dapat dilihat bahwa rata-rata skor subsistem sarana produksi usahatani mentimun di daerah penelitian untuk cara perolehan bibit adalah 2,6 ini berarti cara perolehan bibit menggunakan metode unggul, penggunaan pupuk adalah 2,4 ini berarti pupuk yang digunakan adalah pupuk kimia, jenis pestisida adalah 2,3 ini berarti jenis pestisida yang digunakan adalah pestisida kimia, alat pengolahan lahan adalah 2,6 ini berarti pengolahan lahan menggunakan cangkul dan status penggunaan lahan adalah 2,6 ini berarti status penggunaan lahan adalah milik sendiri.

\section{Subsistem Produksi Usahatani Mentimun}

Untuk lebih jelasnya mengenai ratarata subsistem produksi terhadap pendapatan usahatani mentimun di daerah penelitian dapat dilihat pada tabel IV-4 berikut ini :

Tabel IV-4 : Rata- rata Skor Subsistem Produksi Usahatani Terhadap Pendapatan Usahatani Mentimun di Kecamatan Rantau, 2015.

\begin{tabular}{|l|l|c|c|c|c|c|}
\hline \multirow{2}{*}{ No } & \multirow{2}{*}{$\begin{array}{c}\text { Subsistem Produksi } \\
\text { Usahatani Mentimun }\end{array}$} & \multicolumn{3}{|c|}{ Desa Sampel } & \multirow{2}{*}{ Jumlah } & \multirow{2}{*}{ Rata-rata } \\
\cline { 3 - 4 } & & $\begin{array}{c}\text { Jamur } \\
\text { Jelatang }\end{array}$ & $\begin{array}{c}\text { Jamur } \\
\text { Labu }\end{array}$ & Ingin Jaya & & \\
\hline
\end{tabular}




\begin{tabular}{|l|l|l|l|l|l|l|}
\hline 1. & Sistem Budidaya & 2,6 & 2,6 & 2,4 & 7,7 & 2,6 \\
2. & Pemberantasan Hama & 2,4 & 2,1 & 2,3 & 6,8 & 2,3 \\
3. & Waktu penyiangan & 2,3 & 2,4 & 2,2 & 6,9 & 2,3 \\
4. & Teknologi Budidaya & 2,6 & 2,4 & 2,4 & 7,5 & 2,5 \\
5. & Penggunaan Tenaga Kerja & 2,5 & 2,6 & 2,6 & 7,7 & 2,6 \\
\hline
\end{tabular}

Sumber : Data Primer (diolah), 2015

Dari tabel IV-4 di atas dapat dilihat bahwa rata-rata skor produksi usahatani mentimun untuk sistem budidaya adalah 2,6 ini berarti sistem budidaya yang digunakan adalah khusus, untuk pemberantasan hama adalah 2,3 ini berarti pemberantasan hama pada tanaman mentimun menggunakan cara kimia, untuk waktu penyiangan adalah 2,3 ini berarti waktu penyiangan 2 kali per musim panen, untuk teknologi budidaya adalah 2,5 ini berarti teknologi budidaya yang digunakan adalah intensif dan untuk penggunaan tenaga kerja adalah 2,6 ini berarti penggunaan tenaga kerja adalah campuran.

\section{Subsistem Penanganan Pasca panen Usahatani Mentimun}

Untuk lebih jelasnya mengenai ratarata skor subsistem penanganan pasca panen terhadap pendapatan usahatani mentimun di daerah penelitian dapat dilihat pada tabel IV-5 berikut ini :

Tabel IV-5 : Rata-rata Skor Subsistem Penanganan Pasca panen Terhadap Pendapatan Usahatani Mentimun di Kecamatan Rantau, 2015.

\begin{tabular}{|c|c|c|c|c|c|c|}
\hline \multirow[b]{2}{*}{ No } & \multirow{2}{*}{$\begin{array}{c}\text { Subsistem Penanganan } \\
\text { Pasca panen Usahatani } \\
\text { Mentimun }\end{array}$} & \multicolumn{3}{|c|}{ Desa Sampel } & \multirow[b]{2}{*}{ Jumlah } & \multirow[b]{2}{*}{ Rata-rata } \\
\hline & & $\begin{array}{l}\text { Jamur } \\
\text { Jelatang }\end{array}$ & $\begin{array}{c}\text { Jamur } \\
\text { Labu }\end{array}$ & $\begin{array}{l}\text { Ingin } \\
\text { Jaya }\end{array}$ & & \\
\hline 1. & Waktu Pemanenan & 2,4 & 2,3 & 2,3 & 7,0 & 2,3 \\
\hline 2. & Kualitas Panen Buah & 2,7 & 2,7 & 2,7 & 8,1 & 2,7 \\
\hline 3. & Penyortiran Buah & 2,6 & 2,8 & 2,6 & 8,0 & 2,7 \\
\hline 4. & Arah Pemasaran & 2,7 & 2,7 & 2,6 & 8,0 & 2,7 \\
\hline 5. & Alat Transportasi & 2,6 & 2,3 & 2,3 & 7,3 & 2,4 \\
\hline
\end{tabular}

Sumber : Data Primer (diolah), 2015

Dari tabel IV-5 di atas dapat dilihat bahwa rata-rata skor penanganan pasca panen usahatani mentimun untuk waktu pemanenan adalah 2,3 ini berarti waktu pemanenan mentimun adalah pagi hari, untuk kualitas panen buah adalah 2,7 ini berarti kualitas panen buah mentimun adalah yang sedang, untuk penyortiran buah adalah 2,7 ini berarti penyortiran buah mentimun adalah dengan memilih buah mentimun yang bagus, untuk arah pemasaran adalah 2,7 ini berarti arah pemasaran mentimun langsung ke konsumen dan untuk alat transportasi adalah 2,4 ini berarti alat transportasi yang digunakan adalah sepeda motor.

\section{Penggunaan Tenaga Kerja}

Untuk melihat rata-rata penggunaan tenaga kerja usahatani mentimun di daerah penelitian dapat dilihat pada tabel IV-6 berikut:

Tabel IV-6 : Jumlah Penggunaan Tenaga Kerja Usahatani Mentimun pada Berbagai Fase Kegiatan di Kecamatan Rantau, 2015.

\begin{tabular}{|c|c|c|c|c|c|}
\hline \multirow{3}{*}{ No } & \multirow{3}{*}{ Jenis Kegiatan } & \multicolumn{4}{|c|}{ Penggunaan Tenaga Kerja (HKP) } \\
\hline & & \multicolumn{2}{|c|}{ DK } & \multicolumn{2}{|c|}{ LK } \\
\hline & & Per UT & Per Ha & Per UT & Per Ha \\
\hline 1. & Pengolahan Tanah & 5,79 & 32,19 & 1,70 & 9,44 \\
\hline 2. & Penanaman & 2,47 & 13,70 & 1,83 & 10,19 \\
\hline 3. & Pemeliharaan & $\begin{array}{l}2,20 \\
2,67\end{array}$ & 12,22 & 0 & 0 \\
\hline 4. & Pemupukan & 2,13 & 14,81 & 1,63 & 9,07 \\
\hline 5. & Pengendalian HPT & $\begin{array}{l}2,57 \\
1,87\end{array}$ & 11,85 & 1,77 & 9,81 \\
\hline 6. & Panen & & 14,26 & 1,23 & 6,85 \\
\hline 7. & Penanganan Pasca Panen & & 10,37 & 1,23 & 6,85 \\
\hline & Jumlah & 17,00 & 94,44 & 9,40 & 52,22 \\
\hline
\end{tabular}

Sumber: Data Primer (diolah), 2015

AGRISAMUDRA, Jurnal Penelitian Vol.2 No. 2 Januari-Juni 2015 
Dari tabel IV-6 di atas dapat dilihat bahwa penggunaan tenaga kerja usahatani mentimun di daerah penelitian dalam keluarga (DK) yaitu 17,00 HKP per usahatani dan 94,44 HKP per hektar serta diluar keluarga (LK) yaitu 9,40 HKP per usahatani dan 52,22 HKP per hektar. Penggunaan tenaga kerja terbanyak terdapat pada jenis kegiatan pengolahan tanah yaitu dari dalam keluarga sebesar 5,79 HKP per usahatani dan 32,19 HKP per hektar.

\section{Biaya Produksi}

Biaya produksi di daerah penelitian terbagi atas dua jenis, yaitu biaya tetap (fixed cost) dan biaya variabel (variable cost). Biaya tetap terdiri dari biaya sewa lahan dan biaya penyusutan alat yang dipergunakan seperti cangkul, parang dan handsprayer yang dibayar tunai maupun tidak tunai tetapi diperhitungkan. Biaya variabel terdiri dari benih, pupuk, pestisida dan biaya tenaga kerja. Adapun besarnya biaya produksi yang digunakan petani sampel mentimun dapat dilihat pada tabel IV-7 berikut :

Tabel IV-7 : Rata-rata Penggunaan Biaya Produksi pada Usahatani Mentimun di Kecamatan Rantau, 2015.

\begin{tabular}{|l|l|c|c|c|}
\hline No & \multicolumn{1}{|c|}{ Desa Sampel } & Biaya Tetap (Rp) & Biaya Variabel (Rp) & Biaya Produksi (Rp) \\
\hline 1. & Jamur Jelatang & 306.445 & 2.189 .545 & 2.495 .991 \\
2. & Jamur Labu & 239.500 & 1.608 .100 & 1.847 .600 \\
3. & Ingin Jaya & 210.056 & 1.509 .556 & 1.719 .611 \\
& & & & 2.046 .947 \\
\hline Rata-rata per UT & 255.213 & 1.791 .733 & 11.371 .926 \\
\hline \multicolumn{2}{l}{ Rata-rata per Ha } & 1.417 .852 & 9.954 .074 & \\
\hline
\end{tabular}

Dari tabel IV-7 di atas terlihat bahwa rata-rata biaya produksi usahatani mentimun di daerah penelitian yaitu Rp. 2.046.947,-- per usahatani dan Rp. 11.371.926,- per hektar. Penggunaan biaya produksi terbesar terdapat di Desa Jamur Jelatang yaitu Rp. 2.495.991,-- per usahatani, sedangkan biaya produksi terkecil terdapat di Desa Ingin Jaya yaitu Rp. 1.719.611,-per usahatani.

\section{Produksi dan Nilai Produksi}

Produksi adalah hasil dari balas jasa akibat penggunaan ataupun pemanfaatan faktor-faktor produksi. Selain dipengaruhi oleh kualitas penggunaan faktor-faktor produksi, produksi juga sangat dipengaruhi oleh tingkat kombinasi yang tepat antara faktor-faktor produksi yang dilakukan oleh petani. Produksi yang dihasilkan dapat diukur dalam bentuk fisik yaitu dalam kilogram (Kg). Harga jual mentimun yang berlaku pada saat dilakukan penelitian yaitu Rp. 5.000/Kg. Untuk mengetahui produksi dan nilai produksi usahatani mentimun di daerah penelitian dapat dilihat pada tabel IV-8 berikut.

Tabel IV-8 : Rata-rata Produksi dan Nilai Produksi pada Usahatani Mentimun di Kecamatan Rantau , 2015

\begin{tabular}{|c|l|c|c|}
\hline No & \multicolumn{1}{|c|}{ Desa Sampel } & $\begin{array}{c}\text { Produksi } \\
(\mathrm{Kg})\end{array}$ & $\begin{array}{c}\text { Nilai Produksi } \\
(\mathrm{Rp})\end{array}$ \\
\hline 1. & Jamur Jelatang & 1.136 & 5.681 .818 \\
2. & Jamur Labu & 800 & 4.000 .000 \\
3. & Ingin Jaya & 778 & 3.888 .889 \\
& & & 4.583 .333 \\
\hline & Rata-rata/UT & 917 & 25.462 .963 \\
\hline
\end{tabular}

Sumber : Data Primer (diolah), 2015

Dari tabel IV-8 di atas terlihat bahwa rata-rata produksi usahatani mentimun di daerah penelitian yaitu $917 \mathrm{~kg}$ per usahatani dan 5.093 kg per hektar dengan nilai produksi yaitu Rp. 4.583.333,-- per usahatani dan Rp. 25.462.963,per hektar. Produksi terbesar terdapat di Desa Jamur Jelatang yaitu $1.136 \mathrm{~kg}$ per usahatani dengan nilai produksi Rp. 5.681.818,- per usahatani, sedangkan produksi terkecil terdapat di Desa Ingin Jaya yaitu 778 kg per usahatani dengan nilai produksi Rp. 3.888.889,- per usahatani.

\section{Pendapatan}

Untuk lebih jelasnya pendapatan usahatani mentimun di daerah penelitian dapat dilihat pada tabel berikut :

Tabel IV-9 : Rata-rata Nilai Produksi, Biaya Produksi dan Pendapatan Bersih Usahatani Mentimun di Kecamatan Rantau, 2015

\begin{tabular}{l|l|l|l|l} 
No & Desa Sampel & Nilai Produksi (Rp) & Biaya Produksi (Rp) & Pendapatan (Rp)
\end{tabular}




\begin{tabular}{|c|l|c|c|c|}
\hline 1. & Jamur Jelatang & 5.681 .818 & 2.495 .991 & 3.185 .827 \\
2. & Jamur Labu & 4.000 .000 & 1.847 .600 & 2.152 .400 \\
3. & Ingin Jaya & 3.888 .889 & 1.719 .611 & 2.169 .278 \\
& & & & 2.536 .387 \\
\hline \multicolumn{2}{r|}{ Rata-rata/UT } & 4.583 .333 & 2.046 .947 & 14.091 .037 \\
\hline
\end{tabular}

Sumber : Data Primer (diolah), 2015

Dari tabel di atas terlihat bahwa ratarata pendapatan kotor/nilai produksi usahatani mentimun di daerah penelitian adalah sebesar Rp. 4.583.333,- per usahatani atau Rp. 25.462.963,- per hektar, sedangkan rata-rata biaya produksi usahatani mentimun di daerah penelitian adalah sebesar Rp. 2.046.947,-- per usahatani atau Rp. 11.371.926,- per hektar. Rata-rata pendapatan bersih usahatani mentimun adalah Rp. 2.536.387,- per usahatani atau Rp. 14.091.037,- per hektar.

\section{Analisis R/C Ratio Usahatani Mentimun}

$\mathrm{R} / \mathrm{C}$ adalah singkatan dari Revenue Of Cost Ratio yang merupakan perbandingan (Nisbah) antara penerimaan total (Total Revenue) dengan biaya total yang dikeluarkan (Total Cost). R/C merupakan salah satu alat dalam rangka untuk menilai kelayakan investasi di bidang usahatani, dalam hal ini adalah investasi usahatani mentimun di Kecamatan Rantau Kabupaten Aceh Tamiang, yaitu:

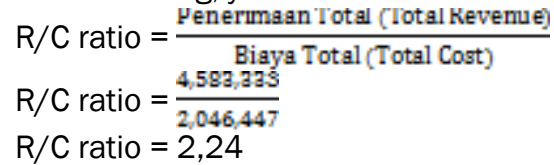

Hasil pengujian $\mathrm{R} / \mathrm{C}$ ratio usahatani mentimun di Kecamatan Rantau Kabupaten Aceh Tamiang diperoleh sebesar 2,24. Ini berarti setiap Rp. 1 modal usaha yang dikeluarkan akan mendapat pengembalian sebesar Rp. 2,24 sehingga menguntungkan dan layak untuk dikembangkan.

Pengaruh Penerapan Subsistem Sarana Produksi, Subsistem Produksi Usahatani dan Subsistem Penanganan Pasca panen Terhadap Pendapatan Usahatani Mentimun

Pengaruh penerapan subsistem sarana produksi, subsistem produksi usahatani dan subsistem penanganan pasca panen terhadap pendapatan usahatani mentimun di daerah penelitian dilakukan dengan menggunakan Persamaan Regresi Linear Berganda dengan 3 variabel bebas yaitu subsistem sarana produksi, subsistem produksi usahatani dan subsistem Tabel IV-10 : Uji Secara Serempak (Uji F), 2015

\begin{tabular}{|c|c|c|c|c|c|}
\hline \multirow[t]{2}{*}{ Variabel } & \multirow[t]{2}{*}{$\mathrm{F}_{\text {cari }}$} & \multicolumn{2}{|c|}{$\mathrm{F}_{\text {tabel }}$} & \multicolumn{2}{|c|}{ Kesimpulan } \\
\hline & & $\begin{array}{l}\alpha= \\
0,05\end{array}$ & $\begin{array}{l}\alpha= \\
0,01\end{array}$ & $\alpha=0,05$ & $\alpha=0,01$ \\
\hline $\begin{array}{l}\text { Subsistem Sarana Produksi }\left(X_{1}\right), \\
\text { Subsistem Produksi Usahatani }\left(X_{2}\right), \\
\text { Subsistem Penanganan Pasca panen }\left(X_{3}\right)\end{array}$ & 20,82 & 2,96 & & $F_{\text {cari }}>F_{\text {tabel }}$ & $F_{\text {cari }}>F_{\text {tabel }}$ \\
\hline
\end{tabular}

penanganan pasca panen. Hasil analisis diperoleh Persamaan Regresi Linear Berganda sebagai berikut:

$Y=-18,89+0,062 X_{1}+0,21 X_{2}+1,41 X_{3}$

Dari persamaan diatas dapat disimpulkan bahwa:

a. Jika subsistem produksi usahatani $\left(X_{2}\right)$ dan subsistem penanganan pasca panen $\left(X_{3}\right)$ dianggap tetap maka setiap penambahan 1 skor penerapan subsistem sarana produksi $\left(X_{1}\right)$ akan menyebabkan penambahan pendapatan usahatani mentimun sebesar Rp. 62.000,

b. Jika subsistem sarana produksi $\left(X_{1}\right)$ dan subsistem penanganan pasca panen $\left(X_{3}\right)$ dianggap tetap maka setiap penambahan 1 skor penerapan subsistem produksi usahatani $\left(\mathrm{X}_{2}\right)$ akan menyebabkan pendapatan usahatani mentimun bertambah sebesar Rp. 210.000,-

c. Jika subsistem sarana produksi $\left(X_{1}\right)$ dan subsistem produksi usahatani $\left(X_{2}\right)$ dianggap tetap maka setiap penambahan 1 skor penerapan subsistem penanganan pasca panen $\left(X_{3}\right)$ akan menyebabkan pendapatan usahatani mentimun bertambah sebesar Rp. 1.410.000,-

Dari hasil perhitungan diperoleh nilai koefisien determinasi $\left(\mathrm{R}^{2}\right)=0,70$ atau $70 \%$. Ini berarti subsistem sarana produksi, subsistem produksi usahatani dan subsistem penanganan pasca panen mempengaruhi pendapatan usahatani mentimun di daerah penelitian sebesar $70 \%$ sedangkan $30 \%$ dipengaruhi oleh faktor-faktor lain diluar penelitian yang tidak dihitung nilainya, seperti faktor harga, permintaan, penawaran dan sebagainya.

Untuk mengetahui besarnya pengaruh penerapan subsistem sarana produksi $\left(X_{1}\right)$, subsistem produksi usahatani $\left(X_{2}\right)$ dan subsistem penanganan pasca panen $\left(X_{3}\right)$ terhadap pendapatan $(\mathrm{Y})$ secara serempak diuji dengan menggunakan uji $\mathrm{F}$, pada tingkat kepercayaan $95 \%(\alpha=0,05)$ dan $99 \%(\alpha=$ $0,01)$ dapat dilihat pada tabel berikut: 


\begin{tabular}{|l|l|l|l|l|l|}
\hline & & & 4,56 & & \\
\hline
\end{tabular}

Berdasarkan tabel di atas, hasil pengujian secara serempak dapat dilihat bahwa $\mathrm{F}$ cari $=20,82>\mathrm{F}$ tabel $=2,96$ pada tingkat kepercayaan $95 \%(\alpha=0,05)$ dan $\mathrm{F}$ tabel $=4,56$ pada tingkat kepercayaan $99 \%(\alpha=0,01)$, ini berarti $\mathrm{F}$ cari $>\mathrm{F}$ tabel pada maka terima $\mathrm{Ha}$ tolak $\mathrm{H}_{0}$ dimana dapat dikatakan bahwa penerapan subsistem sarana produksi, subsistem produksi usahatani dan subsistem penanganan pasca panen secara serempak berpengaruh sangat nyata terhadap pendapatan usahatani mentimun di Kecamatan Rantau Kabupaten Aceh Tamiang. Hal ini karena subsistem sarana produksi, subsistem produksi usahatani dan subsistem penanganan pasca panen yang merupakan bagian dari faktor produksi yang mempengaruhi pendapatan usahatani mentimun.

Untuk mengetahui besarnya pengaruh penerapan subsistem sarana produksi $\left(X_{1}\right)$, subsistem produksi usahatani $\left(X_{2}\right)$ dan subsistem penanganan pasca panen $\left(X_{3}\right)$, terhadap pendapatan $(\mathrm{Y})$ secara parsial diuji dengan menggunakan uji t, pada tingkat kepercayaan $95 \% \quad(\alpha=0,05)$ dan $99 \% \quad(\alpha=$ $0,01)$ dengan $\mathrm{db}=(n-k-1)=30-3-1=26$. Untuk lebih jelasnya hasil perhitungan uji $t$ sebagaimana tertera pada tabel di bawah ini:

Tabel IV-11 : Uji Parsial (uji t), 2015

\begin{tabular}{|c|c|c|c|c|c|}
\hline \multirow[t]{2}{*}{ Variabel } & \multirow[t]{2}{*}{$\mathrm{t}_{\text {cari }}$} & \multicolumn{2}{|c|}{$\mathrm{t}$ tabel } & \multicolumn{2}{|c|}{ Kesimpulan } \\
\hline & & $\alpha=0,05$ & $\alpha=0,01$ & $\alpha=0,05$ & $\alpha=0,01$ \\
\hline - Subsistem Sarana Produksi $\left(\mathrm{X}_{1}\right)$ & 9,48 & 1,7056 & 2,4786 & $\mathrm{t}_{1}$ cari $>\mathrm{t}$ tabel & $\mathrm{t}_{1}$ cari $>\mathrm{t}$ tabel \\
\hline - Subsistem Produksi Usahatani $\left(\mathrm{X}_{2}\right)$ & 23,15 & 1,7056 & 2,4786 & $\mathrm{t}_{2}$ cari $>\mathrm{t}$ tabel & $t_{2}$ cari $>t$ tabel \\
\hline $\begin{array}{l}\text { - Subsistem Penanganan Pasca panen } \\
\left(\mathrm{X}_{3}\right)\end{array}$ & 18,34 & 1,7056 & 2,4786 & $t_{3}$ cari $>$ t tabel & $t_{3}$ cari $>t$ tabel \\
\hline
\end{tabular}

Sumber : Data Primer (diolah), 2015

Berdasarkan tabel di atas, hasil pengujian secara parsial subsistem sarana produksi dapat dilihat bahwa $\mathrm{t}_{1}$ cari $=9,48>\mathrm{t}$ tabel $=1,7056$ pada tingkat kepercayaan $95 \%$ $(\alpha=0,05)$ dan $t$ tabel $=2,4786$ pada tingkat kepercayaan 99\% ( $\alpha=0,01)$ maka terima $\mathrm{Ha}$ dan tolak $\mathrm{H}_{0}$, dimana penerapan subsistem sarana produksi secara parsial berpengaruh sangat nyata terhadap pendapatan pada usahatani mentimun di Kecamatan Rantau Kabupaten Aceh Tamiang.

Hasil pengujian secara parsial untuk subsistem produksi usahatani dapat dilihat bahwa $\mathrm{t}_{2}$ cari $=23,15>\mathrm{t}$ tabel $=1,7056$ pada tingkat kepercayaan 95\% $(\alpha=0,05)$ dan t tabel $=2,4786$ pada tingkat kepercayaan $99 \%(\alpha=$ $0,01)$ maka terima $\mathrm{Ha}$ dan tolak $\mathrm{H}_{0}$, sehingga penerapan subsistem produksi usahatani secara parsial berpengaruh sangat nyata terhadap pendapatan pada usahatani mentimun di Kecamatan Rantau Kabupaten Aceh Tamiang.

Hasil pengujian secara parsial untuk subsistem penanganan pasca panen dapat dilihat bahwa $t_{3}$ cari $=18,34>t$ tabel $=1,7056$ pada tingkat kepercayaan 95\% $(\alpha=0,05)$ dan $\mathrm{t}$ tabel $=2,4786$ pada tingkat kepercayaan $99 \%$ ( $\alpha=0,01$ ) maka terima $\mathrm{Ha}$ dan tolak $\mathrm{H}_{0}$, ini berarti penerapan subsistem penanganan pasca panen secara parsial berpengaruh sangat nyata terhadap pendapatan pada usahatani mentimun di Kecamatan Rantau Kabupaten Aceh Tamiang.

\section{KESIMPULAN DAN SARAN}

\section{Kesimpulan}

Berdasarkan data yang telah dianalisis dan hasil pembahasan maka dapat disimpulkan sebagai berikut :

a. Rata-rata pendapatan kotor/nilai produksi usahatani mentimun didaerah penelitian adalah sebesar Rp. 4.583.333,-/UT atau Rp. 25.462.963,-/Ha, sedangkan rata-rata pendapatan bersih usahatani mentimun adalah Rp. 2.536.387,-/UT atau Rp. 14.091.037,-/Ha.

b. Dari analisis statistik dengan menggunakan Regresi Linier Berganda diperoleh persamaan regresi yaitu $Y=-18,89+0,062$ $X_{1}+0,21 X_{2}+1,41 X_{3}$.

c. Hasil perhitungan diperoleh $\left(\mathrm{R}^{2}\right)=0,70$ atau $70 \%$. Ini berarti subsistem sarana produksi, subsistem produksi usahatani dan subsistem penanganan pasca panen mempengaruhi pendapatan usahatani mentimun di daerah penelitian sebesar $70 \%$ sedangkan 30\% di pengaruhi faktor-faktor lain diluar penelitian yang tidak dihitung nilainya, seperti faktor harga, permintaan, penawaran dan sebagainya.

d. Hasil pengujian secara serempak menunjukkan bahwa subsistem sarana produksi, subsistem produksi usahatani dan subsistem penanganan pasca panen secara 
serempak berpengaruh sangat nyata terhadap pendapatan usahatani mentimun di Kecamatan Rantau Kabupaten Aceh Tamiang.

e. Hasil pengujian secara parsial menunjukkan bahwa subsistem sarana produksi, subsistem produksi usahatani dan subsistem penanganan pasca panen secara parsial berpengaruh sangat nyata terhadap pendapatan usahatani mentimun di Kecamatan Rantau Kabupaten Aceh Tamiang.

\section{Saran}

a. Dalam upaya peningkatan pendapatan usahatani mentimun, diharapakan adanya peningkatan penerapan subsistem agribisnis dengan lebih baik lagi.

b. Sebagaimana koefisien determinasi sebesar 0,70 atau $70 \%$ yang berarti ada sekitar 30\% pendapatan petani mentimun di Kecamatan Rantau Kabupaten Aceh Tamiang dipengaruhi oleh variabel lain yang tidak dimasukkan dalam model penelitian ini. Maka dalam kesempatan ini, penulis menyarankan kepada peneliti selanjutnya untuk mengidentifikasi variabel-variabel lain yang dapat mempengaruhi pendapatan usahatani mentimun.

\section{DAFTAR PUSTAKA}

Anom Wijaya. 2012 . Pengantar Agronomi Sayuran, Prestasi Pustaka, Jakarta.

Anonimous,2011.http://pustaka.unpad.ac.id/wp -conten/uploads/2009/penangananpascapanen-hasil-pertanian.pdf.

Anonimous, 2014. Aceh Tamiang Dalam Angka. Kabupaten Aceh Tamiang

Anonimous. 2014. Potensi Wilayah. Kecamatan Rantau, Kabupaten Aceh Tamiang

Eko Haryanto, dkk. 2007. Sawi \& Selada. Penebar Swadaya. Jakarta

Moehar Daniel, 2004, Pengantar Ekonomi Pertanian, Bumi Aksara Jakarta.

Nazir, M. 2005. Metode Penelitian. Ghalia indonesia. Jakarta.

Rini Sri Dami Hartini. 2005.Jurnal Penyuluhan, Volume I, No. I, September 2005

Sudjana, 2003. Buku Penelitian dan Penilaian. Sinar Baru, Bandung.

Sudjana, 2005. Metode Statistik, CV. Tarsito, Bandung.

Sugiyono, 2010. Metode Penelitian Kuantitatif Kualitatif dan $R$ dan $D$. Alfabeta, Bandung.

Supriati, Y.yulia, dan Ida Nurlela, 2008. Tanaman Sayur. Penebar Swadaya. Jakarta.

Suryani Penti dan Rahmadani Elfi. 2014 Manajemen Agribisnis. Aswaja Pressindo. Yogyakarta

Tjiptono, Fandy. 2008, Strategi Pemasaran, ANDI, 